\title{
Alkoxide Molecular Precursors for Nanomaterials: A One Step Strategy for Oxide Ceramics
}

\author{
Łukasz John and Piotr Sobota \\ University of Wroctaw, Faculty of Chemistry, 14 F. Joliot-Curie St., 50-383 Wrocław
}

Poland

\section{Introduction}

For the last two decades, there has been a growing interest in the development of the chemistry of mixed-metal bi- and polynuclear alkoxo and alkoxo-organometallic complexes. Such interest derives from their fascinating structural chemistry, interesting catalytic properties, and high potential for industrial applications. ${ }^{1}$ The fact that most of the heterometallic alkoxo species can generate bimetallic or multimetallic oxides has resulted in high research activity in the field. The most attractive applicable routes for preparation of oxide materials are those involving alkoxides and their derivatives. First of all, their attractiveness lies in the fact that they are easily accessible and consist inexpensive compounds. Furthermore, alkoxide ligands are easily removable via thermal treatments. Finally, these compounds already have metal-oxygen bonds established. Molecular precursors derive from alkoxide complexes can generate ceramic materials in a single step (so-called single-source precursors - SSPs). ${ }^{2}$ In the case of bi- or polyoxides, such materials deliver appropriate metal elements of a final product eliminating the need to match the reaction rates required from a multicomponent precursor mixture. It is worth noting that their thermal deposition or decomposition processes can be performed at relatively low temperatures compare to conventional methods involving inorganic salts. These features made the metal oxides, that derived from metal alkoxides, highly pure products with specific properties like high hardness, chemical and mechanical resistance, and high temperature stability. From presented above point of view, metal alkoxides play the key role for preparing materials of excellent functions and shapes. The aim of this chapter will be to serve as a guide in understanding the principles in the one step strategy for oxide ceramics using alkoxide precursors. The major accent will be made on design of molecular precursors. The chapter will include synthesis of alkoxides and their derivatives. Among these methods one of the less explored reaction of organometallic complexes with alkoxides that bear free alcohols at the metal site will be discussed. Moreover, it will also contain subchapters describing the concept of SSPs strategy and preparation of oxide materials and their properties. 


\section{Structures of Alkoxides}

Alkoxides $\mathrm{M}(\mathrm{OR})_{\mathrm{x}}(\mathrm{M}=$ metal cation of valency $\mathrm{x} ; \mathrm{R}=$ alkyl or aryl group $)$ are formed by the replacement of the hydroxylic hydrogen of an alcohol $(\mathrm{ROH})$ by a metal cation. According to Bradley's concept, ${ }^{3}$ alkoxides with the lower primary or secondary alkyl groups have a strong tendency to polymerization creating coordination polymers $\left[\mathrm{M}(\mathrm{OR})_{\mathrm{x}}\right]_{\mathrm{y}}$ (where $\mathrm{y}$ is the degree of polymerization). Degree of polymerization increases with the metal atomic ratio. Coordination polymers that they form are relatively smaller than usual organic or silicon polymers. Moreover, alkoxides take the smallest structural unit for the highest possible coordination number of the metal. Metal alkoxides $\left[\mathrm{M}(\mathrm{OR})_{\mathrm{x}}\right]_{\mathrm{y}}$ that are well soluble in common organic solvents, create small oligomers with $y=2,3$, or $4 .^{3}$

Alkoxo $\mathrm{RO}^{-}$anion possesses donor oxygen atom with three unpaired electrons, which form covalent bond with metal. These anions might be coordinated to metal sites in terminal or bridging way. Alkoxides have a tendency to form oligomeric compounds $\left[\mathrm{M}(\mathrm{OR})_{\mathrm{x}}\right]_{\mathrm{y}}$, where $\mathrm{RO}^{-}$groups are connected to two or even more metal sites. This phenomenon is affected on reactivity and properties of these compounds. Heterobi- or heteropolymetallic alkoxo complexes constitute an enormous family of compounds with a very broad structural diversity. These species form structural motifs which range from simple bimetallic compounds to very complex aggregates that result from the versatile coordinating abilities of an alkoxo ligands (Scheme 1$){ }^{4}$

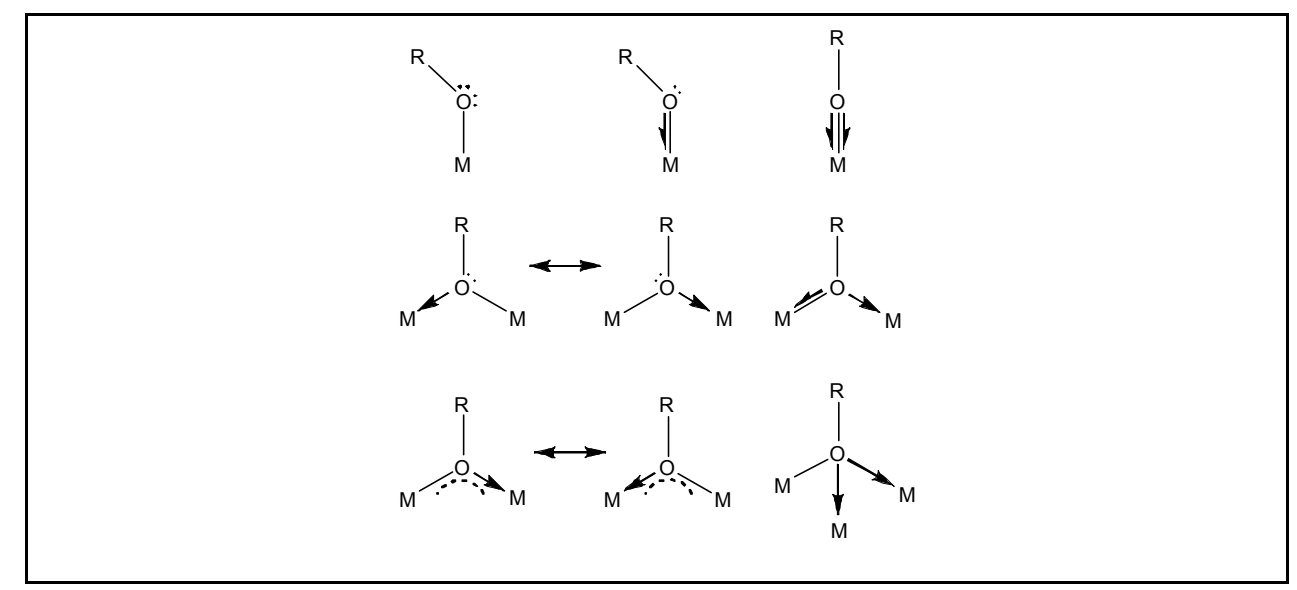

Scheme 1. Coordination modes of an alkoxo ligand according to Bradley, Mehrotra, Rothwell, and Singh.1a

Electron and steric demand of alkoxo groups have an influence on metal alkoxides they form. For instance, the presence of halide or aryl ligands affected on decreasing of electron density onto oxygen atom. Because of these, possibility to form bridging structures is inhibited. Furthermore, electrofilic nature of metal cations allows to attach neutral ligands (e.g. tetrahydrofurane, pyridine, etc.) to the metal spheres. Due to the saturating of metal sites, it is possible to obtain monomeric alkoxides $\left[\mathrm{M}(\mathrm{OR})_{\mathrm{x}} \mathrm{L}_{\mathrm{y}}\right]$ (where $\mathrm{L}=$ neutral ligand).1a Although in the literature there are a lot of examples of metal alkoxides, it would be very 
difficult to formulate a precise rule that could fully explained the process of a specific geometry formation and predict the final geometry of forming alkoxide complex.

\begin{tabular}{|c|c|c|}
\hline Complex & Structural motif & $\begin{array}{c}\operatorname{Ref}_{4} \\
4\end{array}$ \\
\hline$\left[\mathrm{Mg}_{4}\left(\mu_{3}-\mathrm{OMe}\right)_{4}(\mathrm{OMe})_{4}(\mathrm{MeOH})_{8}\right]$ & $\mathrm{Mg}_{4}\left(\mu_{3}-\mathrm{O}\right)_{4} \mathrm{O}_{12}$ core & $\mathrm{b}$ \\
\hline$\left[\mathrm{Ca} 9\left(\mathrm{OCH}_{2} \mathrm{CH}_{2} \mathrm{OCH}_{3}\right)_{18}\left(\mathrm{HOCH}_{2} \mathrm{CH}_{2} \mathrm{OCH}_{3}\right)_{2}\right]$ & $\begin{array}{l}\text { layers of open dicubanes with } \mathrm{Mg}_{4}\left(\mu_{3^{-}}\right. \\
\mathrm{O})_{2}(\mu-\mathrm{O})_{4} \mathrm{O}_{2} \text { core }\end{array}$ & c \\
\hline$\left[\left(\mathrm{C}_{5} \mathrm{H}_{4} \mathrm{CH}_{3}\right)_{4} \mathrm{Y}\left(\mu-\mathrm{OCH}=\mathrm{CH}_{2}\right)\right]_{2}$ & $\mathrm{Y}_{2}(\mu-\mathrm{O})_{2}$ core & $\mathrm{d}$ \\
\hline$\left[\mathrm{Y}_{3}\left(\mu_{3}-\mathrm{O}^{\mathrm{t} B u}\right)\left(\mu_{3}-\mathrm{Cl}\right)\left(\mu-\mathrm{O}^{\mathrm{t} B u}\right)_{3}\left(\mathrm{O}^{\mathrm{t} B u}\right)_{4}(\mathrm{thf})_{2}\right]$ & $\mathrm{Y}_{3}\left(\mu_{3}-\mathrm{O}\right)(\mu-\mathrm{O})_{3} \mathrm{O}_{4}$ core & e \\
\hline$\left[\mathrm{Ti}_{2}(\mu-\mathrm{OR})_{2}(\mathrm{OR})_{4}(\mathrm{acac})_{2}\right]^{\mathrm{a}}\left(\mathrm{R}=\mathrm{Me}, \mathrm{Et},{ }^{\mathrm{i} P r}\right)$ & $\mathrm{Ti}_{2}(\mu-\mathrm{O})_{2} \mathrm{O}_{4}$ core & $\mathrm{f}$ \\
\hline$\left[\mathrm{Me}_{4} \mathrm{Zn}_{4}\left(\mu_{3}-\mathrm{O}^{t} \mathrm{Bu}\right)_{4}\right]$ & $\mathrm{Zn}_{4}\left(\mu_{3}-\mathrm{O}\right)_{4}$ core & $\mathrm{g}$ \\
\hline$\left[\mathrm{W}_{2}\left(\mathrm{OCMe}_{2} \mathrm{CMe}_{2} \mathrm{O}\right)_{3}\right]$ & $\mathrm{O}_{3} \mathrm{~W} \equiv \mathrm{WO}_{3}$ core & $\mathrm{h}$ \\
\hline$\left[\mathrm{Ga}_{2}\left(\mu-\mathrm{O}^{\mathrm{t}} \mathrm{Bu}\right)_{2}{ }^{\mathrm{t}} \mathrm{Bu}_{4}\right]$ & $\mathrm{Ga}_{2}(\mu-\mathrm{O})_{2}$ core & $\mathrm{i}$ \\
\hline$\left[\mathrm{Mg}_{2} \mathrm{~V}_{2} \text { (thffo) }{ }_{6} \mathrm{Cl}_{4}\right]^{\mathrm{b}}$ & $\mathrm{Mg}_{2} \mathrm{~V}_{2}\left(\mu_{3}-\mathrm{O}\right)_{2}(\mu-\mathrm{O})_{4}$ core & j \\
\hline$\left.\left[(\text { thf })\left(\mathrm{O}^{\mathrm{t} B u}\right) \mathrm{Y}^{\prime}\left(\mu-\mathrm{O}^{\mathrm{t}} \mathrm{Bu}\right)\left(\mu-\mathrm{CH}_{3}\right) \mathrm{AlMe}_{2}\right\}_{3}\right]$ & $\mathrm{YAl}_{3}(\mu-\mathrm{O})_{3} \mathrm{O}$ core & $\mathrm{k}$ \\
\hline$\left[\mathrm{Zr}_{2} \mathrm{Co}_{2}\left(\mu_{3}-\mathrm{O} \mathrm{Pr}\right)_{2}(\mu-\mathrm{OnPr})_{4}\left(\mathrm{O}^{n} \mathrm{Pr}\right)_{4}(\mathrm{acac})_{2}\right]^{\mathrm{a}}$ & $\mathrm{Zr}_{2} \mathrm{Co}_{2}\left(\mu_{3}-\mathrm{O}\right)_{2}(\mu-\mathrm{O})_{4} \mathrm{O}_{4}$ core & 1 \\
\hline$\left[\mathrm{Al}\left\{(\mathrm{OEt})_{2} \mathrm{GaMe}_{2}\right\}_{3}\right]$ & $\mathrm{AlGa}_{3}(\mu-\mathrm{O})_{6}$ core & $\mathrm{m}$ \\
\hline$\left[\mathrm{Nb}_{2}(\mu-\mathrm{OMe})_{2}(\mathrm{OMe})_{2}(\mathrm{HOMe})_{2} \mathrm{Cl}_{4}\right]$ & $\mathrm{Nb}-\mathrm{Nb}(\mu-\mathrm{O})_{2} \mathrm{O}_{4}$ core & $\mathrm{n}$ \\
\hline$\left[\mathrm{Mo}_{2}(\mathrm{O} \mathrm{Pr})_{4}(\mathrm{HO} \mathrm{Pr})_{4}\right]$ & $\mathrm{O}_{4} \mathrm{Mo}=\mathrm{MoO}_{4}$ core & o \\
\hline$\left[\mathrm{Pb}\left(\mu-\mathrm{OC}_{2} \mathrm{H}_{4} \mathrm{OMe}\right)_{2}\right]_{\mathrm{n}}$ & chain structure with $\mathrm{Pb}(\mu-\mathrm{O})_{2}$ core & $\mathrm{p}$ \\
\hline [ $\left.\mathrm{Y}_{10}\left(\mathrm{OCH}_{2} \mathrm{CH}_{2} \mathrm{OMe}\right)_{30}\right]$ & $\begin{array}{l}\text { cyclic decameric structure with } \mathrm{Y}(\mu-\mathrm{O})_{2} \mathrm{O} \\
\text { core }\end{array}$ & $\mathrm{r}$ \\
\hline$\left[\operatorname{Pr}_{3}\left(\mu_{3}-\mathrm{tftb}\right)_{2}(\mu-\mathrm{tftb})_{3}(\mathrm{tftb})_{2}\right]^{\mathrm{c}}$ & $\operatorname{Pr}_{3}\left(\mu_{3}-\mathrm{O}\right)_{2}(\mu-\mathrm{O})_{3} \mathrm{O}_{4}$ core & $\mathrm{s}$ \\
\hline$\left[\left\{\mathrm{Co}_{8}(\mathrm{\mu}-\mathrm{OMe})_{16}\left(\mathrm{O}_{2} \mathrm{CMe}\right)_{8}\right\}\left(\mathrm{NH}_{4}^{+}\right)\right]$ & $\begin{array}{l}\text { cyclic structure with } \mathrm{NH}_{4}{ }^{+} \text {guest and } \\
\mathrm{Co}(\mu-\mathrm{O})_{16} \mathrm{O}_{16} \text { core }\end{array}$ & $\mathrm{t}$ \\
\hline$\left[\mathrm{YNa}{ }_{8}\left(\mu_{9}-\mathrm{Cl}\right)\left(\mu_{4}-\mathrm{O}^{\mathrm{t}} \mathrm{Bu}\right)\left(\mu_{3}-\mathrm{O}^{\mathrm{t} B u}\right)_{8}\left(\mathrm{O}^{\mathrm{t}} \mathrm{Bu}\right)\right]$ & $\mathrm{YNa}_{8}\left(\mu_{4}-\mathrm{O}\right)\left(\mu_{3}-\mathrm{O}\right)_{8} \mathrm{O}$ core & $\mathrm{u}$ \\
\hline$\left[\mathrm{Na}_{4} \mathrm{Zr}_{6}\left(\mu_{5}-\mathrm{O}\right)_{2}\left(\mu_{3}-\mathrm{OEt}\right)_{4}(\mu-\mathrm{OEt})_{14}(\mathrm{OEt})_{6}\right]$ & $\mathrm{Na}_{4} \mathrm{Zr}_{6}\left(\mu_{5}-\mathrm{O}\right)_{2}\left(\mu_{3}-\mathrm{O}\right)_{4}(\mu-\mathrm{O})_{14} \mathrm{O}_{6}$ core & $\mathrm{v}$ \\
\hline$\left[\mathrm{Ti}_{7}\left(\mu_{4}-\mathrm{O}\right)\left(\mu_{3}-\mathrm{O}\right)_{2}(\mu-\mathrm{OEt})_{8}(\mathrm{OEt})_{12}\right]$ & $\mathrm{Ti}_{7}\left(\mu_{4}-\mathrm{O}\right)\left(\mu_{3}-\mathrm{O}\right)_{2}(\mu-\mathrm{O})_{8} \mathrm{O}_{12}$ core & $\mathrm{w}$ \\
\hline
\end{tabular}

Table 1. Different structural motifs of metal alkoxides.

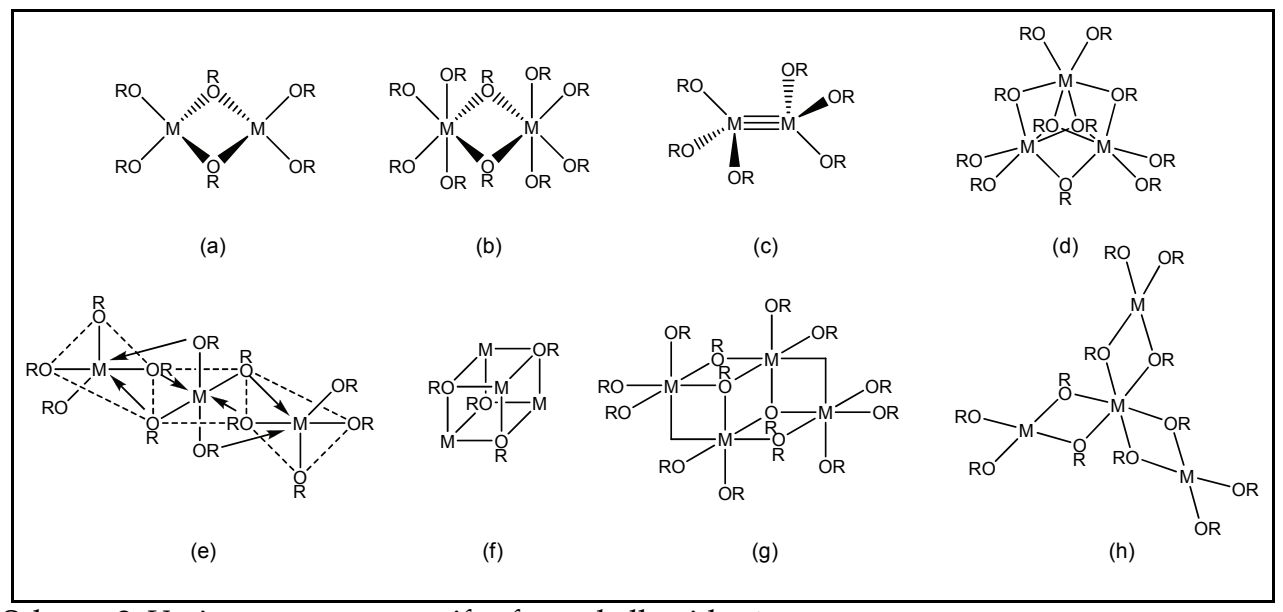

Scheme 2. Various structure motifs of metal alkoxides. ${ }^{1 a}$ 
In fact even minor changes in a ligand structure or reaction conditions can cause the geometry of the whole compound to be fundamentally different. To the most common alkoxide structural motifs are included (Scheme 2): (a) $\left[\mathrm{M}_{2}(\mu-\mathrm{OR})_{2}(\mathrm{OR})_{4}\right]$ with $\mathrm{M}_{2} \mathrm{O}_{6}$ core, (b) [ $\left.\mathrm{M}_{2}(\mu-\mathrm{OR})_{2}(\mathrm{OR})_{8}\right]$ with $\mathrm{M}_{2} \mathrm{O}_{10}$ core, (c) $\left[\mathrm{M}_{2}(\mathrm{OR})_{6}\right]$ with $\mathrm{M}_{2} \mathrm{O}_{6}$ core and triple bond between metal sites, (d) $\left[\mathrm{M}_{3}\left(\mu_{3}-\mathrm{OR}\right)_{2}(\mu-\mathrm{OR})_{3}(\mathrm{OR})_{4}(\mathrm{HOR})_{2}\right]$ with $\mathrm{M}_{3} \mathrm{O}_{11}$ core, $(\mathrm{e})\left[\mathrm{M}_{3}(\mu-\mathrm{OR})_{6}(\mathrm{OR})_{6}\right]$ with $\mathrm{M}_{3} \mathrm{O}_{12}$ core, (f) $\left[\mathrm{M}_{4}\left(\mu_{3}-\mathrm{OR}\right)_{4}\right]$ with $\mathrm{M}_{4} \mathrm{O}_{4}$ core, $(\mathrm{g})\left[\mathrm{M}_{4}(\mu-\mathrm{OR})_{2}(\mu-\mathrm{OR})_{4}(\mathrm{OR})_{10}\right]$ with $\mathrm{M}_{4} \mathrm{O}_{10}$ core, and $(\mathrm{h})\left[\mathrm{M}_{4}(\mu-\mathrm{OR})_{6}(\mathrm{OR})_{6}\right]$ with $\mathrm{M}_{4} \mathrm{O}_{12}$ core units. A few examples from the wide geometrical palette of alkoxo species are shown in Table 1.4

\section{Alkoxides - General Methods of Synthesis}

There are many methods of synthesis of metal alkoxides or aryloxides. Their choice depends on the ionization energy of the metal, which alkoxide is formed. The less electronegative alkali metals react spontaneously with alcohols, but for instance magnesium, aluminium etc. need some so-called activation agent, e.g. small amounts of crystalline $\mathrm{I}_{2}$ or $\mathrm{HgCl}_{2}$. For other metals more complex reactions need to be applied. Below, we will briefly discuss the most common methods of synthesis.

\subsection{Direct reaction of metal with an alcohol}

This method is the most popular in laboratory scale but limited to less electronegative alkali metals ( $\mathrm{Li}, \mathrm{Na}, \mathrm{K}, \mathrm{Rb}, \mathrm{Cs}$ ). It is based on hydroxyl hydrogen substitution by appropriate metal cation accompanied by intense heat and $\mathrm{H}_{2}$ evolution (Eq. 1):

$$
\mathrm{M}+(1+\mathrm{x}) \mathrm{ROH} \rightarrow 1 / \mathrm{y}\{\mathrm{MOR} \cdot x \mathrm{ROH}\}_{\mathrm{y}}+1 / 2 \mathrm{H}_{2} \uparrow
$$

Second group metals possess higher ionization energy and are liable to passive process. Because of this, their reactions are much slower than with group 1 metals. Well soluble alkoxides can be obtained in direct reaction using sterically ramified alcohols (where $\mathrm{R}=$ ${ }^{t} \mathrm{Bu}, \mathrm{CF}_{3}$, aryl etc.). ${ }^{5}$ The use of alcohols with "bulky" $\mathrm{R}$ groups prevent oligomerization, and resulting alkoxides are well soluble in common aliphatic hydrocarbons.

\subsection{Electrochemical method}

Synthesis of metal alkoxides by anodic dissolution of metals in alcohols was firstly used in 1906 by Szilard et al. for copper and lead methoxides. ${ }^{6}$ In the seventies of the last century, this technique was spread by Lehmkhul et al. for the synthesis of $\mathrm{M}(\mathrm{OR})_{2}$ complexes (where $\mathrm{M}$ is $\left.\mathrm{Fe}^{2+}, \mathrm{Co}^{2+}, \mathrm{Ni}^{2+} ; \mathrm{R}=\mathrm{Me}, \mathrm{Et},{ }^{\mathrm{nBu}}{ }^{\mathrm{t}} \mathrm{Bu}\right){ }^{7}$ Electrode processes can be summarized as follows: Due to the oxidation of metal at the anode, cation and electron are formed. The electron and alcohol create hydrogen radical $\mathrm{H}^{*}$ and alkoxide anion. Molecular hydrogen is exude at the cathode. Because of electrode reactions appropriate cations and anions RO- are obtained.7 This method is employed of metals with high ionization energy. It is easy, effective technique, and final products are extremely pure. At present, electrochemical method is applied in synthesis of $\mathrm{Y}, \mathrm{Ti}, \mathrm{Zr}, \mathrm{Nb}, \mathrm{Ta}, \mathrm{Mo}, \mathrm{W}, \mathrm{Cu}, \mathrm{Ge}, \mathrm{Sn}$, etc. alkoxides. ${ }^{8}$ 


\subsection{Reaction of alcohols with metal halides}

The reaction between alcohol and metal halide leads to the substitution of halide anion into RO- group forming appropriate metal alkoxide (Eq. 2).

$$
\mathrm{MCl}_{\mathrm{z}}+(\mathrm{x}+\mathrm{y}) \mathrm{ROH} \rightarrow \mathrm{MCl}_{\mathrm{z}-\mathrm{x}}(\mathrm{OR})_{\mathrm{x}}(\mathrm{ROH})_{\mathrm{y}}+\mathrm{xHCl}{ }^{\uparrow}
$$

Depending on the solvent, molar ratio of reagents, and temperature, different compounds can be obtained. Classic example is a reaction of $\mathrm{TiCl}_{4}$ with $\mathrm{PrOH}$ in $\mathrm{CH}_{2} \mathrm{Cl}_{2}$, where $[\mathrm{Ti}(\mu-$ $\left.\mathrm{Cl}_{2} \mathrm{Cl}_{2}(\mathrm{O} \mathrm{Pr})_{4}\right],\left[\mathrm{TiCl}_{3}(\mathrm{O} \mathrm{Pr})(\mathrm{HO} \mathrm{Pr})_{2}\right]$, and $\left[\mathrm{Ti}_{2} \mathrm{Cl}_{4}(\mu-\mathrm{O} \mathrm{Pr})_{2}(\mathrm{O} \mathrm{Pr})_{2}(\mathrm{HO} \mathrm{Pr})_{2}\right]$ are formed ${ }^{9}$

\subsection{Reactions of alcohols with metal hydroxides and oxides}

Metal hydroxides and oxides react with alcohols forming appropriate alkoxides and water (Eqs. 3-4).

$$
\begin{gathered}
\mathrm{M}(\mathrm{OH})_{\mathrm{x}}+\mathrm{xROH} \rightleftarrows \mathrm{M}(\mathrm{OR})_{\mathrm{x}}+\mathrm{xH}_{2} \mathrm{O} \\
\mathrm{MO}_{\mathrm{x}}+2 \mathrm{x} \mathrm{ROH} \rightleftarrows \mathrm{M}(\mathrm{OR})_{2 \mathrm{x}}+\mathrm{xH}_{2} \mathrm{O}
\end{gathered}
$$

Due to the reversible nature of these reactions, it is necessary to remove water from the reaction system. This method applies to receive alkoxides, both main and side groups of metals. ${ }^{10}$

\subsection{Ligands exchange reactions}

One of the characteristic properties of metal alkoxides is their activity in the substitution reactions of alkoxo groups (Eq. 5). In this way several homo- and heteroleptic alkoxide complexes were synthesized. ${ }^{11}$

$$
\mathrm{M}(\mathrm{OR})_{\mathrm{x}}+\mathrm{yR} \mathrm{R}^{\prime} \mathrm{OH} \rightarrow \mathrm{M}(\mathrm{OR})_{\mathrm{x}-\mathrm{y}}(\mathrm{OR})_{\mathrm{y}}+\mathrm{yROH}
$$

Ligands exchange reactions are affected: (a) the steric ramified of the $\mathrm{RO}$ and $\mathrm{R}^{\prime} \mathrm{O}$ groups, (b) the values of $\mathrm{H}-\mathrm{O}$ bond energies, and (c) the relative $\mathrm{M}-\mathrm{O}$ bond strengths.

\subsection{Reactions of alcohols with metal amides}

Dialkyl amides $\mathrm{M}\left(\mathrm{NR}_{2}\right)_{\times}\left(\mathrm{R}=\mathrm{Me}, \mathrm{Et}, \mathrm{SiMe}_{3}\right)$ react with alcohols according to below equation (Eq. 6):

$$
\mathrm{M}\left(\mathrm{NR}_{2}\right)_{\mathrm{x}}+\mathrm{xR} \mathrm{R}^{\prime} \mathrm{OH} \rightarrow \mathrm{M}\left(\mathrm{OR}^{\prime}\right)_{\mathrm{x}}+\mathrm{xR}_{2} \mathrm{NH}^{\uparrow}
$$

This method is useful for metals that have a higher affinity for oxygen atoms, rather than to nitrogen. Its advantage is that forming dialkyl amines are easy to remove from the reaction environment and resulting alkoxide product is highly pure. ${ }^{12}$ 


\subsection{Reactions of alcohols with organometallics}

Reactions of organometallics with alcohols are quite popular in the literature. ${ }^{13}$ These reactions are extremely useful for the preparation of mono- and mixed-metal alkoxides (Eqs. 7-9) but their disadvantage is that organometallics are air/moisture sensitive and working with them is cumbersome.

$$
\begin{gathered}
\mathrm{MR}_{2}+\mathrm{R}^{\prime} \mathrm{OH} \rightarrow 1 / \mathrm{x}\left[\mathrm{MOR}^{\prime}\right]_{\mathrm{x}}+\mathrm{RH} \uparrow \\
\mathrm{MR}_{3}+\mathrm{R}^{\prime} \mathrm{OH} \rightarrow 1 / \mathrm{x}\left[\mathrm{R}_{2} \mathrm{MOR}^{\prime}\right]_{\mathrm{x}}+\mathrm{RH}^{\uparrow} \\
\mathrm{R}_{2} \mathrm{MX}+\mathrm{M}^{\prime} \mathrm{OR}^{\prime} \rightarrow 1 / \mathrm{x}\left[\mathrm{R}_{2} \mathrm{MOR}^{\prime}\right]_{\mathrm{x}}+\mathrm{M}^{\prime} \mathrm{X}
\end{gathered}
$$

Very interesting modification of this reaction is a direct reaction of organometallic complexes with alkoxides that bear free alcohols at the metal site (Eq. 10). ${ }^{14}$

$$
\mathrm{M}(\mathrm{OR})_{\mathrm{x}}(\mathrm{ROH})_{\mathrm{y}}+\mathrm{y} \mathrm{M}^{\prime} \mathrm{R}_{\mathrm{z}}^{\prime} \rightarrow \mathrm{M}^{\prime} \mathrm{R}_{\mathrm{z}-1}^{\prime} \mathrm{M}(\mathrm{OR})_{\mathrm{x}+\mathrm{y}}
$$

In this reaction there is an organometallic driven abstraction of the $\mathrm{OH}$ hydrogens from $\mathrm{M}$ coordination sphere. This leads to the subsequent evolution of simple hydrocarbons like methane or ethane and results in a linkage of RO ligands. Because of the simple gases evolution, resulting products are highly pure.

\section{A One Step Strategy for Oxide Ceramics}

Mono- and mixed-metal alkoxides with fixed ratio of participating metals can be used for oxide ceramic preparation via thermolysis to give high purity materials. Metal alkoxides as so-called single-source precursors (SSPs) already have metal-oxygen bonds established. Because of this, their thermal decomposition can be performed at relatively low temperatures and maintains the $\mathrm{M}-\mathrm{O}$ core. What is extremely important here, the metal oxides derived from alkoxide SSPs are highly pure and have specific properties like high hardness, chemical and mechanical resistance, and high temperature stability. They constitute a group of advanced ceramics. ${ }^{4 a}$

Bimetallic SSPs can generate ceramic materials in a single step. Their advantage over the inorganic salt mixtures lies in the fact that both or more elements of a final product eliminating the need to match the reaction rates required from a multicomponent precursor mixture in conventional methods. ${ }^{15}$ In general, careful and appropriate choice of metals and alkoxo ligands is necessary in this strategy if undesired side reactions occur.

Interesting and useful classification of SSPs was proposed by Veith.16 This approach is based on their differences in thermal decomposition/deposition pathways. Approach discussed can be subdivided into three different types of precursors: SSP-I, SSP-II, and SSP-III.

\subsection{SSP-I}

In the first type of SSPs, metals stoichiometry on molecular level of precursor is also present in a correct ratio of the final oxide product (Eq. 11).

$$
\mathrm{MM}^{\prime} \mathrm{LL}^{\prime} \rightarrow \mathrm{MM}^{\prime}{ }_{\mathrm{x}}+\mathrm{L}+\mathrm{L}^{\prime}
$$


$\mathrm{M}$ and $\mathrm{M}^{\prime}$ are denoted oxide units. $\mathrm{L}$ and $\mathrm{L}^{\prime}$ are ligands which can survive thermolysis conditions unchanged or they can be modified during this process.

Complexes $\left[\mathrm{BaM}(\mathrm{OH})(\mathrm{O} P r)_{5}(\mathrm{HO} P r)_{3}\right]_{2}$ (where $\mathrm{M}=\mathrm{Ti}, \mathrm{Zr}$ ) and $\left[\mathrm{BaTi}_{0.5} \mathrm{Zr}_{0.5}(\mathrm{OiPr})_{6}\right]_{2}$ constitute the examples of SSP-I (Fig. 1). ${ }^{17}$ From these precursors perovskites and related perovskites $\mathrm{BaTiO}_{3}, \mathrm{BaZrO}_{3}$ and $\mathrm{BaTi}_{0.5} \mathrm{Zr}_{0.5} \mathrm{O}_{3}$, respectively, were obtained.

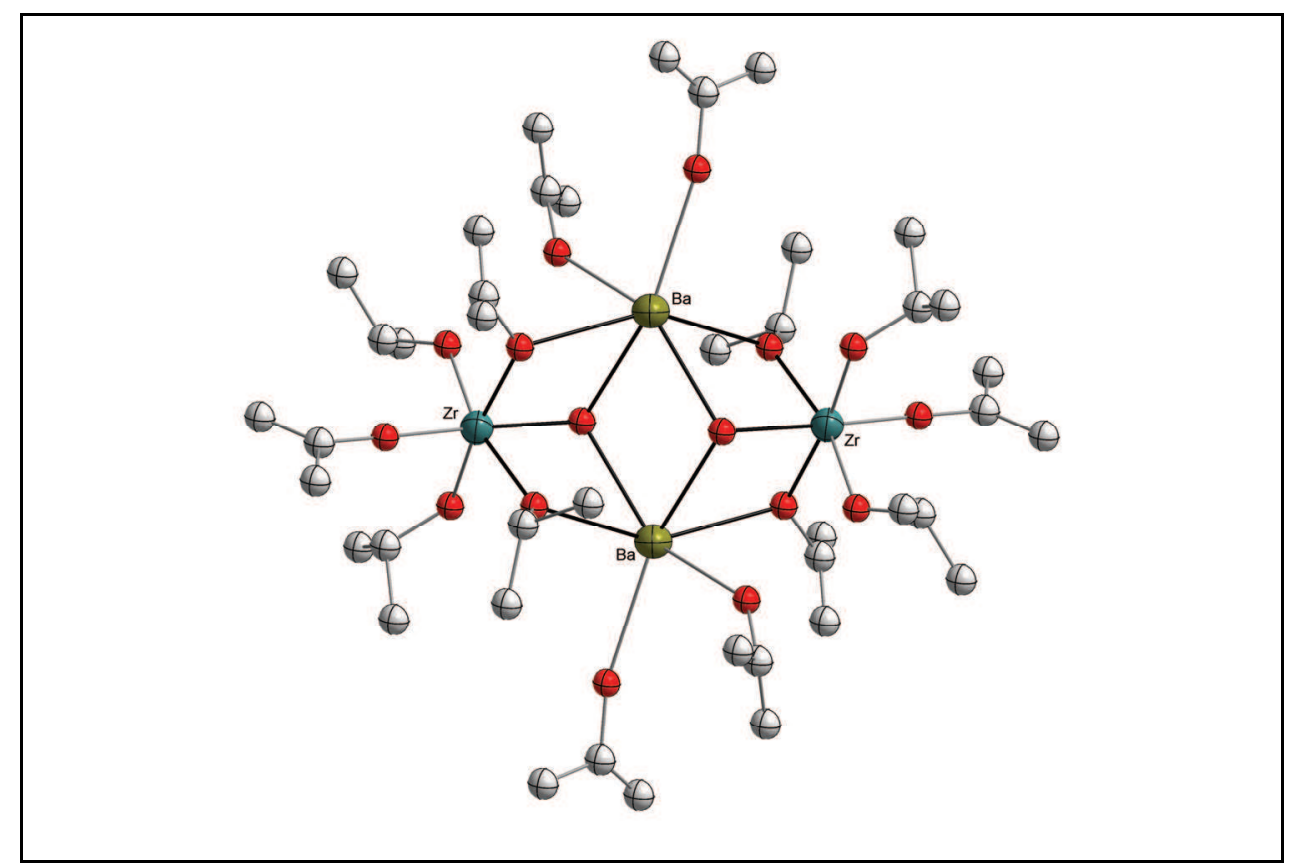

Fig. 1. Molecular structure of $\left[\mathrm{BaZr}(\mathrm{OH})(\mathrm{OiPr})_{5}(\mathrm{HO} \text { Pr })_{3}\right]_{2}$ (the $\mathrm{H}$ atoms are omitted for clarity). ${ }^{17 b}$

\subsection{SSP-II}

In this case, $\mathrm{M}$ and $\mathrm{M}^{\prime}$ components are in the same stoichiometry in the precursor and final oxide product (Eq. 12).

$$
\mathrm{MM}_{\mathrm{x}} \mathrm{LL}^{\prime} \rightarrow \mathrm{MM}_{\mathrm{x}}{ }+\mathrm{L}-\mathrm{L}^{\prime}
$$

Moreover, ligands $\mathrm{L}$ and $\mathrm{L}^{\prime}$ are chosen in such a way that react with each other. Because of this phenomenon, final products are well-defined volatiles and the presence of undesired side products is limited. Complex $\left[\mathrm{Ba}\left\{(\mu-\mathrm{OR})_{2} \mathrm{AlEt}_{2}\right\}_{2}\right]$ (where $\mathrm{ROH}=2,3$-dihydro-2,2dimethylbenzofuran-7-ol) is an example of SSP-II. Its thermal decomposition leads to $\mathrm{BaAl}_{2} \mathrm{O}_{4}$ spinel-like heterobimetallic oxide ceramic (Fig. 2). ${ }^{14}$ 


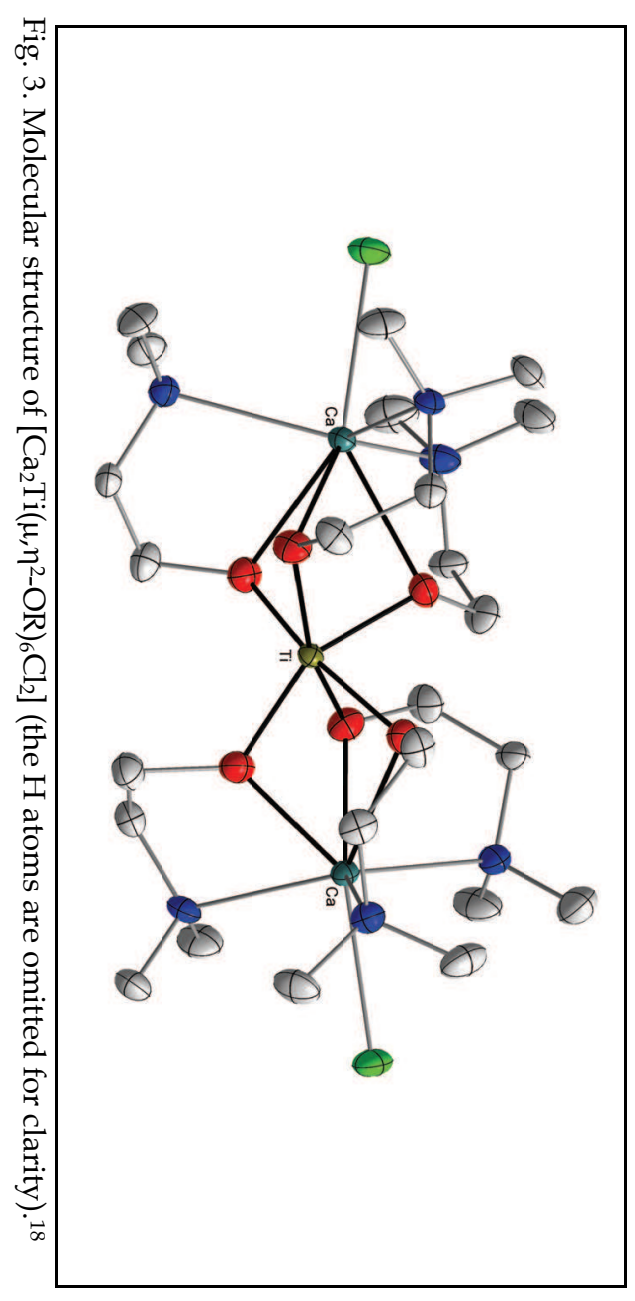

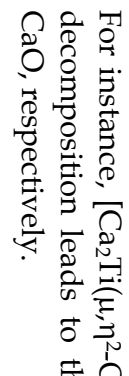

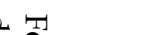




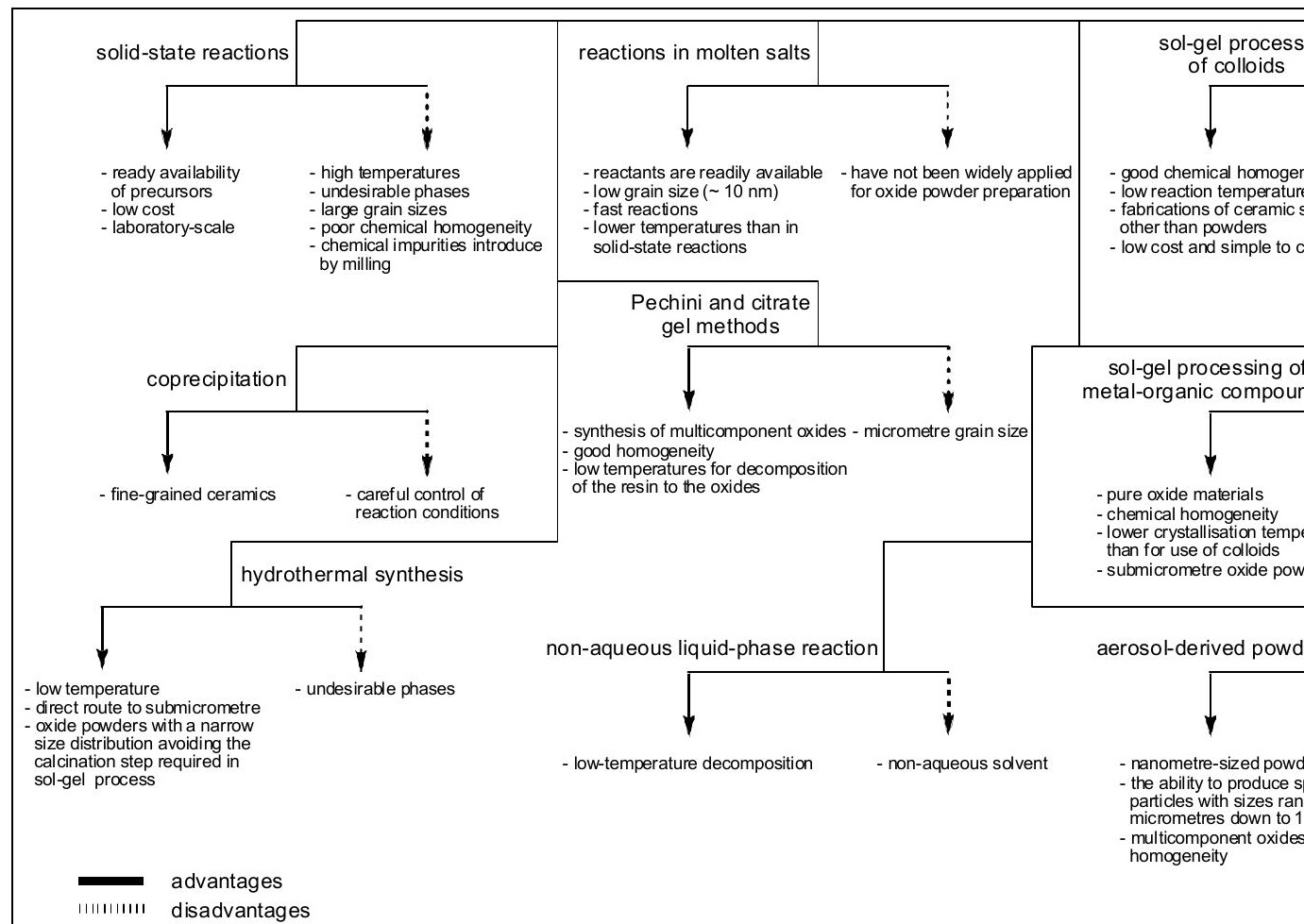

Scheme 3. Applicable routes for preparation of oxide materials. ${ }^{4 a}$ 


\section{Alkoxides as the SSPs for Oxides}

In the following section we will illustrate the above types of SSPs by examples taken from our studies. These examples are restricted to oxide ceramics, in which only oxide phases are present. The major key point of this discussion will be emphasized on synthetic approach for this kind of materials.

Why do alkoxides and their derivatives are in the center of interest in materials science? Metal alkoxides are inexpensive compounds which are quite easy to obtain in laboratory scale. Because of the close contact of metal-oxygen bonds, they have already prepared, on molecular level, network for oxide materials. Complement of all of these advantages is that alkoxide ligands are easy to removed during thermal treatments leaving stable $\mathrm{M}-\mathrm{O}$ core. From these point of view, they are perfect candidates for single-source precursors for oxide ceramic materials. Unfortunately, in general these kind of precursors are extremely air and moisture sensitive. For example titanium alkoxides $\mathrm{Ti}(\mathrm{OR})_{4}$ are not easy to store and working with them can be cumbersome, especially with those possessing small OR groups (where $\mathrm{R}=\mathrm{Me}, \mathrm{Et}$, $\mathrm{Pr}$ ). Oxophilic metal site of $\mathrm{M}(\mathrm{OR})_{\mathrm{x}}$ containing small monodentate ligands can be protected against air and moisture decomposition by larger bi- or polydentate ligands for some or all of the alkoxides OR groups. The most popular strategy utilizes functionalized alcohols with additional ether oxygen or amine nitrogen atoms. Such precursors are not only less moisture sensitive. The greater steric demand of the bulky ligands and the increased donor ability of the additional donor atoms are the advantages in forming monomeric or dimeric complexes, which is favourable for instance in the CVD applications. ${ }^{19}$

There are a number of well-known applicable routes for preparation of oxide materials using inorganic and organic precursors. The most common chemical approaches to these are presented in Scheme 3. Among these methods, the most attractive are those involving alkoxides and their derivatives.

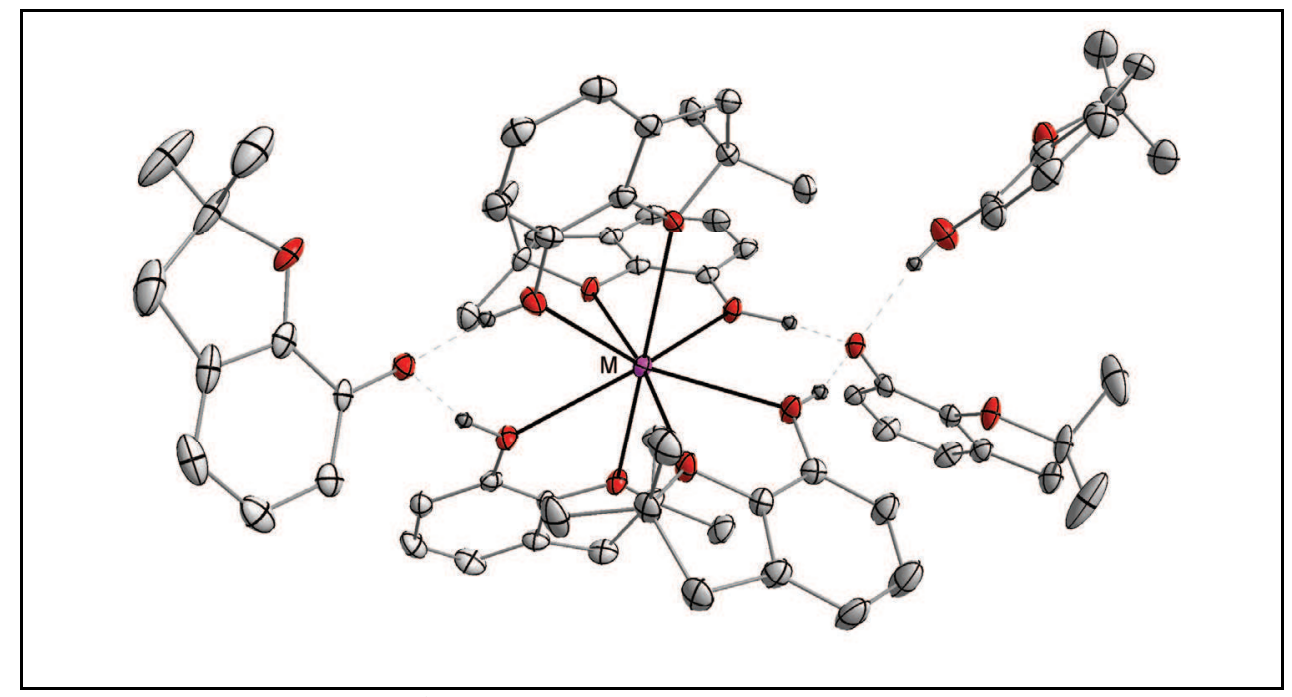

Fig. 4. Molecular structure of $\left[\mathrm{M}(\mathrm{ddbfoH})_{4}\right](\mathrm{ddbfo})_{2} \cdot \mathrm{ddbfoH}\left(\right.$ where $\left.\mathrm{M}=\mathrm{Sr}^{2+}, \mathrm{Ba}^{2+}\right) .{ }^{20}$ 
In our research we were mainly interested in heterobi- and heteropolymetallic alkoxides of different transition metals with group 2 elements. As an initial point of this strategy we have obtained well-defined homoleptic alkoxides, which constituted starting materials for further transformations. Group 2 metals create divalent ions and prefer high coordination numbers, e.g. six, eight and higher. For example, the reaction for barium or strontium gave monomeric, ionic complexes in which the central atom is eight-coordinated and surrounded by four chelating ligands and additionally solvated by three $\mathrm{RO}(\mathrm{H})$ groups (Fig. 4).

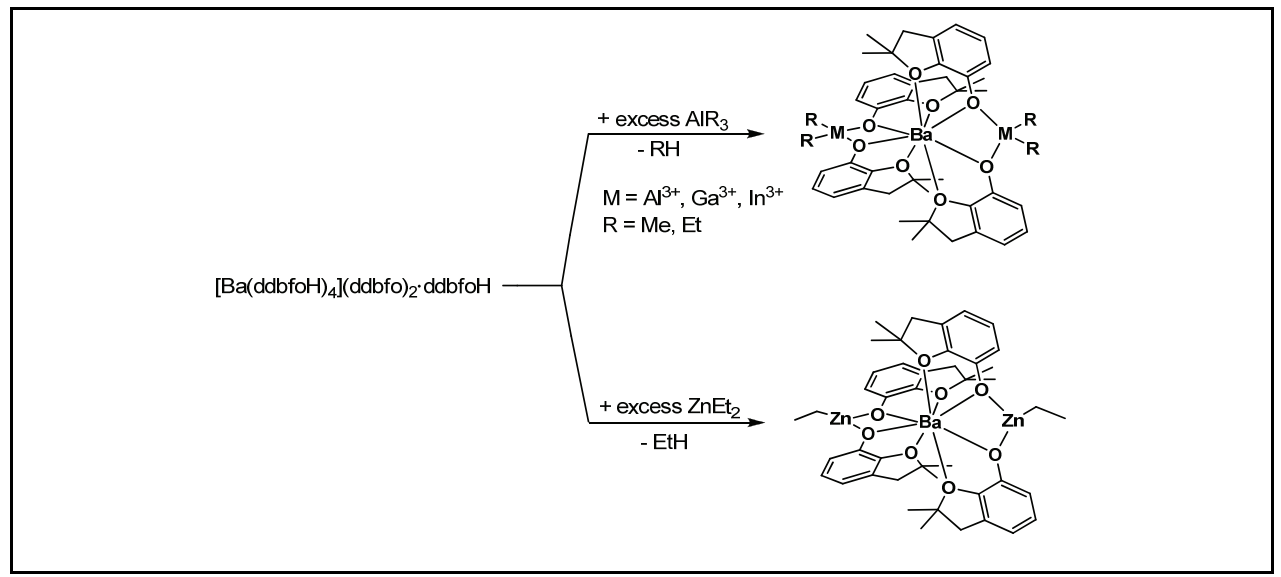

Scheme 4 . Syntheses of heterobimetallic barium/group 12 and 13 complexes. ${ }^{14}$

It is worth noting that there are not so many examples of crystallographically characterized homoleptic complexes of these metals in the literature. In the case of the ligands, we have mainly concentrated on chelating functionalized alcohols possessing two or more donor atoms, for example ether-alcohols like 2,3-dihydro-2,2-dimethylbenzofuran-7-ol (ddbfoH), tetrahydrofurfuryl alcohol (thffoH), 2-methoxyethanol $\left(\mathrm{CH}_{3} \mathrm{OCH}_{2} \mathrm{CH}_{2} \mathrm{OH}\right)$ and aminealcohols, for instance $\mathrm{N}, \mathrm{N}$-dimethylethanolamine $\left(\mathrm{Me}_{2} \mathrm{NCH}_{2} \mathrm{CH}_{2} \mathrm{OH}\right)$ etc.

Several studies have shown that starting compounds which possess a protonated hydroxyl group(s) at the metal site are perfect anchor for other organometallic fragments. ${ }^{14,21}$ The concept of the proposed synthetic route is presented in Scheme 4. In general, the driving force for this reactions is an organometallic-driven abstraction of the $\mathrm{OH}$ protons from the $\mathrm{ROH}$ groups attached to the metal sphere. This leads to the simple alkanes (e.g. methane, ethane etc.) evolution and results in a linkage of $\mathrm{RO}$ ligands with appropriate $\mathrm{MR}_{\mathrm{x}}{ }^{+}$moieties (where $\mathrm{M}=\mathrm{Zn}^{2+}, \mathrm{Al}^{3+}, \mathrm{Ga}^{3+}, \mathrm{In}^{3+} ; \mathrm{R}=\mathrm{Me}, \mathrm{Et} ; \mathrm{x}=1,2$ ).

For monometallic homoleptic SSPs with no free alcohol ligands in metal coordination sphere, a different reaction pathway is observed. For example, oligomeric magnesium or calcium alkoxides which possesses open dicubane geometry (Scheme $2 \mathrm{~g}$ ) do not have any possibility for simple hydrocarbon eliminations. A direct reaction of $\left[\mathrm{Ca}_{4}(\mathrm{OR})_{8}\right](\mathrm{ROH}=2,3-$ dihydro-2,2-dimethylbenzofuran-7-ol) with $\mathrm{AlMe}_{3}$ in toluene leads to deoligomerization of the starting alkoxide and cocomplexation of $\mathrm{AlMe}_{3}$, forming the molecular dimeric tetranuclear adduct $\left[\mathrm{Ca}(\mu-\mathrm{OR})\left\{(\mu-\mathrm{OR})\left(\mu-\mathrm{CH}_{3}\right) \mathrm{Al}\left(\mathrm{CH}_{3}\right)_{2}\right\}\right]_{2}$ shown in Fig. 5. ${ }^{22}$

As mentioned-above, alkoxides have a strong tendency to oligomerization. The oligomeric structure can easily be broken by addition of organometallics or even weak donors to 
reaction system. Our previous studies clearly show that the strategy of blocking the bridging alkoxo groups to deoligomerize calcium alkoxides and obtain low-nuclearity species works effectively. The general idea of this phenomenon is presented in Scheme 5. For instance, the addition of THF to oligomeric calcium-aluminium complexes leads to the formation of the molecular six-coordinate adduct (Fig. 6).

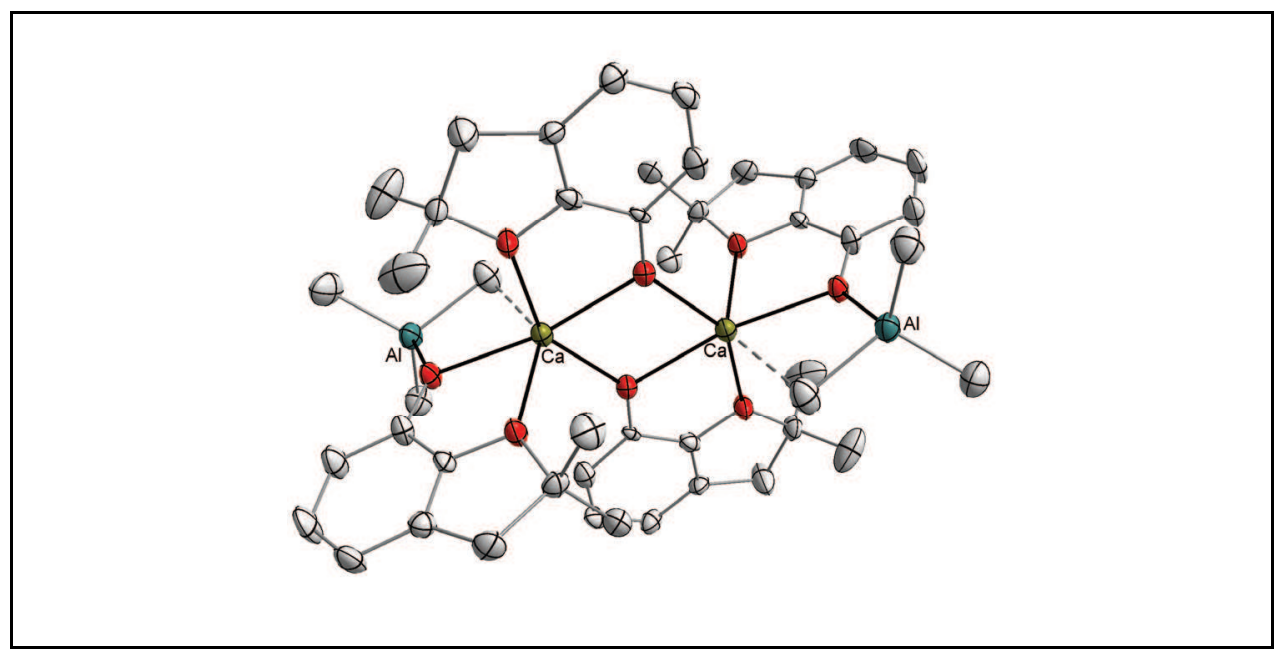

Fig. 5. Molecular structure of $\left[\mathrm{Ca}(\mu-\mathrm{OR})\left\{(\mu-\mathrm{OR})\left(\mu-\mathrm{CH}_{3}\right) \mathrm{Al}\left(\mathrm{CH}_{3}\right)_{2}\right\}\right]_{2}$ (the $\mathrm{H}$ atoms are omitted for clarity). ${ }^{22}$

These examples demonstrate that the alkoxo groups responsible for oligomerization of metal alkoxides can be easily blocked with organometallic agents and donor solvents to prevent agglomeration. ${ }^{22}$

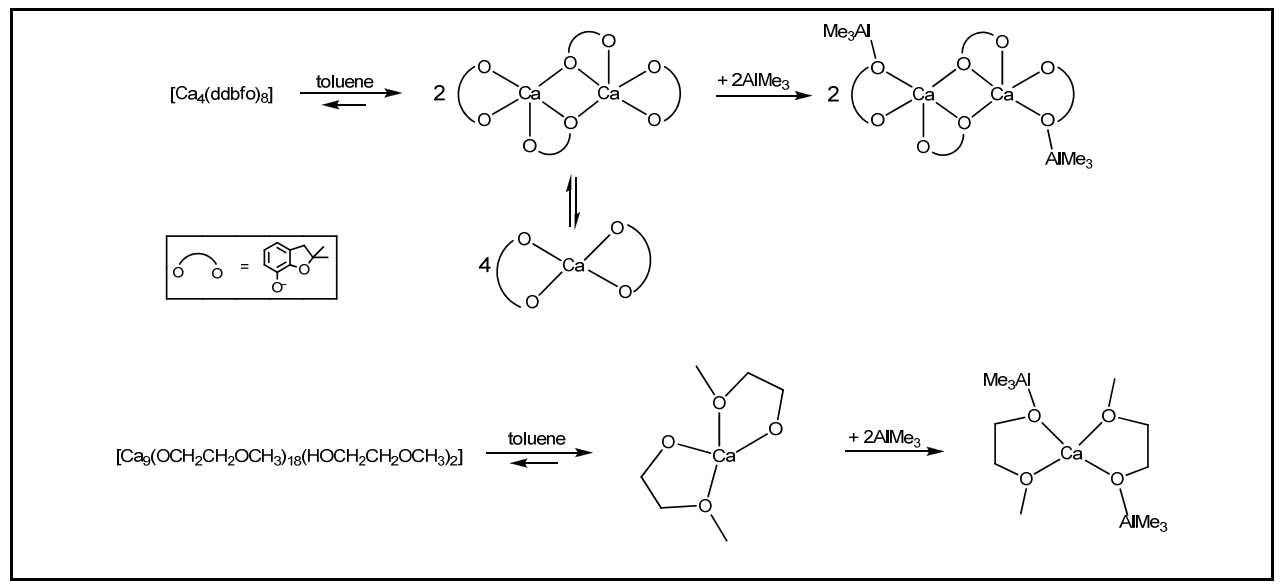

Scheme 5. General idea of blocking alkoxo oxygen atoms by $\mathrm{AlMe}_{3}$. 
Interesting group of single-source precursors constitute chloro-alkoxides. Generally chloride-substituted alkoxides are considered as inefficient precursors for metal oxides. One of the disadvantages is that $\mathrm{Cl}$ ligands are corrosive agents.

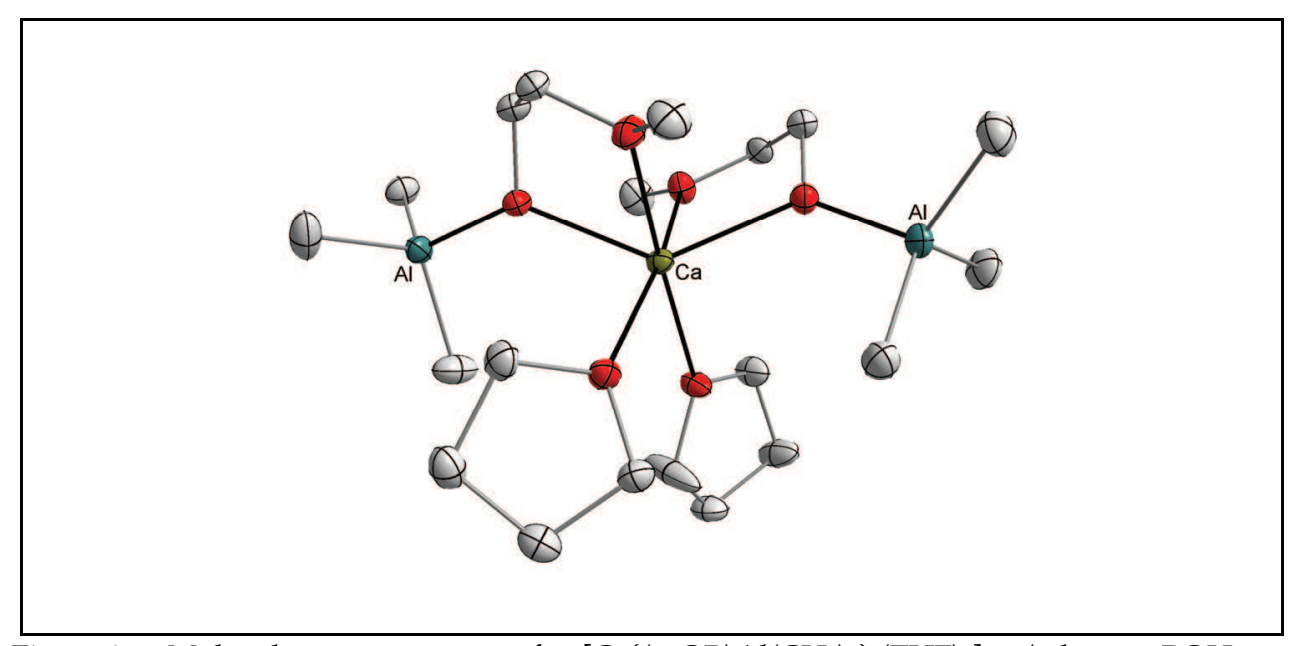

Fig. 6. Molecular structure of $\left[\mathrm{Ca}\left\{(\mu-\mathrm{OR}) \mathrm{Al}\left(\mathrm{CH}_{3}\right)_{3}\right\}_{2}(\mathrm{THF})_{2}\right]$ (where $\mathrm{ROH}=$ $\mathrm{CH}_{3} \mathrm{OCH}_{2} \mathrm{CH}_{2} \mathrm{OH}$ ) (the $\mathrm{H}$ atoms are omitted for clarity).

Moreover, in many cases oxide material is contaminated by $\mathrm{Cl}$-products. However, in the literature there are a few examples of chloro-alkoxides utilized as the SSPs for highly pure oxide ceramics. ${ }^{23}$ For instance, $\left[\mathrm{Zn}_{7}(\mathrm{OAc})_{10}(\mu-\mathrm{OH})_{6} \mathrm{Cu}_{5}\left(\mathrm{dmae}_{4} \mathrm{Cl}_{4}\right]\right.$ (where dmaeH $=(\mathrm{N}, \mathrm{N}-$ dimethylamino)ethanol), which was used in the chemical vapor deposition and gave copper-zinc $\mathrm{Cu}_{5} \mathrm{Zn}_{7} \mathrm{O}_{12}$ double-oxide and possesses metal to metal stoichiometry fixed on molecular level. 24

Another efficient and simple strategy involves reaction of cheap organometallic $\mathrm{Cp}_{2} \mathrm{MCl}_{2}$ (where $\mathrm{M}=\mathrm{Ti}^{4+}, \mathrm{Zr}^{4+}, \mathrm{Hf}^{4+}$ ) with $\mathrm{M}^{\prime}(\mathrm{OR})_{2}$ (where $\mathrm{M}^{\prime}=\mathrm{Ca}^{2+}, \mathrm{Sr}^{2+}, \mathrm{Ba}^{2+}, \mathrm{Mn}^{2+}$; $\mathrm{ROH}=$ functionalized alcohol) in the presence of alcohol. General idea is presented bellow (Eq. 14).

$$
2 \mathrm{Cp}_{2} \mathrm{MCl}_{2}+4 \mathrm{M}^{\prime}(\mathrm{OR})_{2}+8 \mathrm{ROH} \rightarrow\left[\mathrm{M}_{4}^{\prime} \mathrm{M}_{2}(\mathrm{O}) \mathrm{Cl}_{4}(\mathrm{OR})_{10}(\mathrm{HOR})_{4}\right]+4 \mathrm{CpH}+\text { by-product(s) }
$$

In this method formation of $\mathrm{M}^{\prime}-\mathrm{Cl}$ bond constitutes the driving force for this reaction. As a source of protons functionalized alcohols, e.g. $\mathrm{CH}_{3} \mathrm{OCH}_{2} \mathrm{CH}_{2} \mathrm{OH}$ or $\mathrm{Me}_{2} \mathrm{NCH}_{2} \mathrm{CH}_{2} \mathrm{OH}$ can be used. Using this synthetic approach a series of heterobimetallic complexes were obtained (Table 2). ${ }^{18}$

All of these compounds possess interesting molecular structures, especially those with octahedral geometry. Generally, their metallic cores can be described as follows: first, as an octahedron with six metal sites and a $\mu_{6}-\mathrm{O}^{2-}$ encapsulated oxygen atom in the central position and each of the triangular faces being capped by a $\mu_{3}$-oxygen atom from OR group (Fig. 7a). Second motif, as a cube formed by the eight oxygen atoms of the alkoxide groups, with metal cations located outside of the six faces of the cube and $\mathrm{O}^{2-}$ anion occupying the central position (Fig. $7 \mathrm{~b}$ ). In third core type, octahedral unit in which each edge of polyhedron is alternatively capped by $\mu_{2^{-}}$ $\mathrm{O}$ (alkoxide) groups or $\mu_{2}-\mathrm{Cl}$ anions (Fig. 7c). ${ }^{18}$ 
Although the mentioned-above complexes possess chloride ligands, they are attractive precursors for highly phase pure binary metal oxides. For instance, thermal decomposition of $\left[\mathrm{Ba}_{4} \mathrm{Ti}_{2}\left(\mu_{6}-\mathrm{O}\right) \mathrm{Cl}_{4}\left(\mathrm{OCH}_{2} \mathrm{CH}_{2} \mathrm{OCH}_{3}\right)_{10}\left(\mathrm{HOCH}_{2} \mathrm{CHOCH}_{3}\right)_{4}\right]$ leads to the mixture of $\mathrm{BaTiO}_{3}$ and $\mathrm{BaCl}_{2}$. Barium dichloride is easily removed by washing the resulting powder with water. Because of the presence of group 2 cations of the precursor, obtaining chloride is stable (ionic bond) at the temperature of perovskite phase appearing.

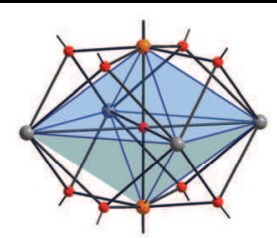

(a)

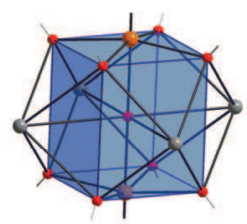

(b)

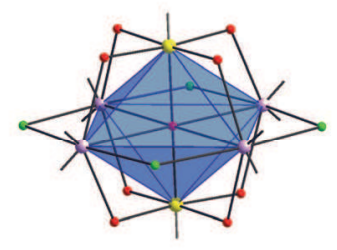

(c)

Fig. 7. View of the octahedral cores.

\begin{tabular}{|c|c|}
\hline Compound & Ref. \\
\hline$\left[\mathrm{Ca}_{4} \mathrm{Ti}_{2}\left(\mu_{6}-\mathrm{O}\right)\left(\mu_{3}, \eta^{2}-\mathrm{OR}\right)_{8}(\eta-\mathrm{OR})_{2} \mathrm{Cl}_{4}\right]$ & $18 \mathrm{a}$ \\
\hline$\left[\mathrm{Sr}_{4} \mathrm{Hf}_{2}\left(\mu_{6}-\mathrm{O}\right)\left(\mu_{3}, \eta^{2}-\mathrm{OR}\right)_{8}(\eta-\mathrm{OR})_{2}(\eta-\mathrm{HOR})_{4} \mathrm{Cl}_{4}\right]$ & $18 \mathrm{a}$ \\
\hline$\left[\mathrm{Ca}_{4} \mathrm{Zr}_{2}\left(\mu_{6}-\mathrm{O}\right)(\mu-\mathrm{Cl})_{4}\left(\mu, \eta^{2}-\mathrm{OR}\right)_{8} \mathrm{Cl}_{2}\right]$ & $18 \mathrm{a}$ \\
\hline$\left[\mathrm{Sr}_{4} \mathrm{Ti}_{2}\left(\mu_{6}-\mathrm{O}\right)\left(\mu_{3}, \eta^{2}-\mathrm{OR}\right)_{8}(\eta-\mathrm{OR})_{2}(\eta-\mathrm{HOR})_{2} \mathrm{Cl}_{4}\right]$ & $18 \mathrm{a}$ \\
\hline$\left[\mathrm{Ca}_{4} \mathrm{Zr}_{2} \mathrm{Cp}_{2}\left(\mu_{4}-\mathrm{Cl}\right)(\mu-\mathrm{Cl})_{3}\left(\mu_{3}, \eta^{2}-\mathrm{OR}\right)_{4}\left(\mu, \eta^{2}-\mathrm{OR}\right)_{4} \mathrm{Cl}_{2}\right]$ & $18 \mathrm{a}$ \\
\hline$\left[\mathrm{CaTiCl}_{2}\left(\mu, \eta^{2}-\mathrm{OR}^{\prime}\right)_{3}\left(\eta-\mathrm{HOR}^{\prime}\right)_{3}\right]\left[\mathrm{OR}^{\prime}\right]$ & $18 \mathrm{a}$ \\
\hline$\left[\mathrm{Ca}_{2} \mathrm{Ti}\left(\mu, \eta^{2}-\mathrm{OR}^{\prime}\right)_{6} \mathrm{Cl}_{2}\right]$ & $18 \mathrm{a}$ \\
\hline$\left[\mathrm{Mn}_{4} \mathrm{Ti}_{4}(\mu-\mathrm{Cl})_{2}\left(\mu_{3}, \eta^{2}-\mathrm{OR}\right)_{2}\left(\mu, \eta^{2}-\mathrm{OR}\right)_{10} \mathrm{Cl}_{6}\right]$ & $18 \mathrm{a}$ \\
\hline$\left[\mathrm{Mn}_{10} \mathrm{Zr}_{10}\left(\mu_{4}-\mathrm{O}\right)_{10}\left(\mu_{3}-\mathrm{O}\right)_{4}\left(\mu_{3}, \eta^{2}-\mathrm{OR}\right)_{2}\left(\mu, \eta^{2}-\mathrm{OR}\right)_{16}(\mu, \eta-\mathrm{OR})_{4}(\eta-\mathrm{OR})_{2} \mathrm{Cl}_{8}\right]$ & $18 \mathrm{a}$ \\
\hline$\left[\mathrm{Ba}_{4} \mathrm{Ti}_{2}\left(\mu_{6}-\mathrm{O}\right) \mathrm{Cl}_{4}(\mathrm{OR})_{10}(\mathrm{HOR})_{4}\right]$ & $18 \mathrm{~b}$ \\
\hline$\left[\mathrm{Ba}_{4} \mathrm{Zr}_{2}\left(\mu_{6}-\mathrm{O}\right) \mathrm{Cl}_{4}(\mathrm{OR})_{10}(\mathrm{HOR})_{4}\right]$ & $18 b$ \\
\hline$\left[\mathrm{Ba}_{4} \mathrm{Hf}_{2}\left(\mu_{6}-\mathrm{O}\right) \mathrm{Cl}_{4}(\mathrm{OR})_{10}(\mathrm{HOR})_{4}\right]$ & $18 \mathrm{~b}$ \\
\hline $\mathrm{ROH}=\mathrm{CH}_{3} \mathrm{OCH}_{2} \mathrm{CH}_{2} \mathrm{OH} ; \mathrm{R}^{\prime} \mathrm{OH}=\mathrm{Me}_{2} \mathrm{NCH}_{2} \mathrm{CH}_{2} \mathrm{OH}$ & \\
\hline
\end{tabular}

Table 2. Examples of series heterometallic chloro-alkoxides obtained from $\mathrm{Cp}_{2} \mathrm{MCl}_{2}$ precursors.

The above presented alkoxide complexes seem to be natural candidates for oxide ceramic materials. They have already designed oxygen-bound units that bring metal atoms close one to another. Furthermore, they also have a fixed ratio of metals appropriate for desired oxide 
systems. It is worth noting here, that compounds possessing steric ramified ligands, e.g. aryloxo, decompose in much more complicated way, compare to alkoxides with small RO groups (e.g. $\mathrm{Me}, \mathrm{Et}$, iPr etc.).

In general, metal complexes with chelating and bulky aryloxo ligands are non-volatile and much more stable in contrast to monodentate alkoxides. Hence, thermal decomposition of metal aryloxo derivatives is much more complex and usually a long lasting process. In each case the decomposition is multi-step with mass losses that do not clearly correspond to an extrusion of a specific number of leaving ligands. ta, $^{14}$

In Table 3, there are a few examples of synthesized SSPs and corresponding with them monoand double-oxide ceramic materials.

\begin{tabular}{|c|c|c|}
\hline SSP & Oxide(s) & Ref. \\
\hline$\left[\mathrm{Me}_{2} \mathrm{Al}(\mu-\mathrm{ddbfo})\right]_{2^{\mathrm{a}}}$ & $\mathrm{Al}_{2} \mathrm{O}_{3}$ & 25 \\
\hline$\left[\mathrm{Me}_{2} \operatorname{In}(\mu-\mathrm{ddbfo})\right]_{2^{\mathrm{a}}}$ & $\mathrm{In}_{2} \mathrm{O}_{3}$ & 25 \\
\hline$\left[\mathrm{Ti}_{2}(\mu-\mathrm{ddbfo})_{2}(\mathrm{ddbfo})_{6}\right]^{\mathrm{a}}$ & $\mathrm{TiO}_{2}$ & 26,27 \\
\hline$\left.\left[\mathrm{Ti}(\mathrm{O} \text { Pr })_{2} \text { (maltolato }\right)_{2}\right]^{\mathrm{b}}$ & $\mathrm{TiO}_{2}$ & 26,28 \\
\hline$\left[(\mathrm{VO}) \mathrm{Cl}_{\mathrm{x}}\left(\mathrm{OCH}_{3}\right)_{\mathrm{y}}\right]^{\mathrm{c}}$ & $\mathrm{V}_{2} \mathrm{O}_{5}$ & $23 a$ \\
\hline$\left[\mathrm{Ba}\left\{(\mu-\mathrm{ddbfo})_{2} \mathrm{AlMe}_{2}\right\}_{2}\right]^{\mathrm{a}}$ & $\mathrm{BaAl}_{2} \mathrm{O}_{4}$ & 14 \\
\hline$\left[\mathrm{Ba}\left\{(\mu-\mathrm{ddbfo})_{2} \mathrm{GaMe}_{2}\right\}_{2}\right]^{\mathrm{a}}$ & $\mathrm{BaGa}_{2} \mathrm{O}_{4}$ & 14 \\
\hline$\left[\mathrm{Ca}\left\{\left(\mu-\mathrm{OCH}_{2} \mathrm{CH}_{2} \mathrm{OCH}_{3}\right)(\mu-\mathrm{Me})\left(\mathrm{AlMe}_{2}\right)\right\}_{2}\right]$ & $\mathrm{CaAl}_{2} \mathrm{O}_{4}$ & 22,25 \\
\hline$\left[\mathrm{Ca}\left\{\left(\mu-\mathrm{OCH}_{2} \mathrm{CH}_{2} \mathrm{OCH}_{3}\right)\left(\mathrm{AlMe}_{3}\right)\right\}_{2}(\mathrm{THF})_{2}\right]$ & $\mathrm{CaAl}_{2} \mathrm{O}_{4}$ & 22,25 \\
\hline$\left[\mathrm{CaTiCl}_{2}\left(\mu, \eta^{2}-\mathrm{OCH}_{2} \mathrm{CH}_{2} \mathrm{NMe}_{2}\right)_{3}(\eta-\right.$ & \multirow[t]{2}{*}{$\mathrm{CaTiO}_{3}$} & \multirow[t]{2}{*}{$18 \mathrm{a}$} \\
\hline $\left.\left.\mathrm{OCH}_{2} \mathrm{CH}_{2} \mathrm{NMe}_{2}\right)_{3}\right]\left[\mathrm{OCH}_{2} \mathrm{CH}_{2} \mathrm{NMe}_{2}\right]$ & & \\
\hline$\left[\mathrm{Ca}_{2} \mathrm{Ti}\left(\mu, \eta^{2}-\mathrm{OCH}_{2} \mathrm{CH}_{2} \mathrm{NMe}_{2}\right)_{6} \mathrm{Cl}_{2}\right]$ & $\mathrm{CaTiO}_{3}+\mathrm{CaO}$ & $18 \mathrm{a}$ \\
\hline$\left[\mathrm{MnAl}(\mathrm{acac})_{3}(\mathrm{OiPr})_{4}(\mathrm{OAc})\right]^{\mathrm{d}}$ & $\mathrm{MnAl}_{2} \mathrm{O}_{4}$ & 29 \\
\hline$\left[\mathrm{CoAl}(\mathrm{acac})_{3}(\mathrm{OiPr})_{4}(\mathrm{OAc})\right]^{\mathrm{d}}$ & $\mathrm{CoAl}_{2} \mathrm{O}_{4}$ & 29 \\
\hline$\left[\mathrm{ZnAl}(\mathrm{acac})_{3}(\mathrm{OiPr})_{4}(\mathrm{OAc})\right]^{\mathrm{d}}$ & $\mathrm{ZnAl}_{2} \mathrm{O}_{4}$ & 29 \\
\hline$\left[\mathrm{NiAl}_{2}(\mathrm{acac})_{4}(\mathrm{OiPr})_{4}\right]^{\mathrm{d}}$ & $\mathrm{NiAl}_{2} \mathrm{O}_{4}$ & 30 \\
\hline$\left[\mathrm{MgAl}_{2}(\mathrm{O} \mathrm{Pr})_{8}\right]$ & $\mathrm{MgAl}_{2} \mathrm{O}_{4}$ & 31 \\
\hline$\left[\mathrm{MgAl}_{2}\left(\mathrm{O}^{\mathrm{t} B u}\right)_{8}\right]$ & $\mathrm{MgAl}_{2} \mathrm{O}_{4}$ & 31 \\
\hline$\left[\mathrm{Nd}\left\{\mathrm{Al}(\mathrm{OiPr})_{4}\right\}_{3}(\mathrm{PrOH})\right]$ & $\mathrm{NdAlO}_{3}+\mathrm{Al}_{2} \mathrm{O}_{3}$ & 32 \\
\hline$\left[\mathrm{Ba}_{4} \mathrm{Ti}_{2}\left(\mu_{6}-\mathrm{O}\right) \mathrm{Cl}_{4}\left(\mathrm{OCH}_{2} \mathrm{CH}_{2} \mathrm{OCH}_{3}\right)_{10}\left(\mathrm{HOCH}_{2} \mathrm{CHOCH}_{3}\right)_{4}\right]$ & $\mathrm{BaTiO}_{3}$ & $18 b$ \\
\hline$\left[\mathrm{Ba}_{4} \mathrm{Zr}_{2}\left(\mu_{6}-\mathrm{O}\right) \mathrm{Cl}_{4}\left(\mathrm{OCH}_{2} \mathrm{CH}_{2} \mathrm{OCH}_{3}\right)_{10}\left(\mathrm{HOCH}_{2} \mathrm{CHOCH}_{3}\right)_{4}\right]$ & $\mathrm{BaZrO}_{3}$ & $18 \mathrm{~b}$ \\
\hline$\left[\mathrm{Ba}_{4} \mathrm{Hf}_{2}\left(\mu_{6}-\mathrm{O}\right) \mathrm{Cl}_{4}\left(\mathrm{OCH}_{2} \mathrm{CH}_{2} \mathrm{OCH}_{3}\right)_{10}\left(\mathrm{HOCH}_{2} \mathrm{CHOCH}_{3}\right)_{4}\right]$ & $\mathrm{BaHfO}_{3}$ & $18 b$ \\
\hline$\left[\mathrm{Ba}\left\{(\mu-\mathrm{ddbfo})_{2} \operatorname{InMe}\right\}_{2}\right]^{\mathrm{a}}$ & $\mathrm{BaIn}_{2} \mathrm{O}_{4}$ & 25 \\
\hline$\left[\operatorname{Sr}\left\{(\mu-\mathrm{ddbfo})_{2} \mathrm{AlMe}_{2}\right\}_{2}\right]^{\mathrm{a}}$ & $\mathrm{SrAl}_{2} \mathrm{O}_{4}$ & 25 \\
\hline $\begin{array}{l}\text { addbfoH }=2,3 \text {-dihydro-2,2-dimethylbenzofuran-7-ol; } \\
\text { pyran-4-one }) ; c(x+y)=4 ; \text { dacac = acetylacetonato. }\end{array}$ & 3-hydroxy-2-1 & $y 1-4 \mathrm{H}-$ \\
\hline
\end{tabular}

Table 3. Examples of various oxide ceramic materials derived from SSPs.

\section{Conclusion}

In this chapter, we have shown that metal alkoxides are extremely attractive starting materials for oxide ceramics. They constitute so-called single source precursors (SSPs), which major advantage is that their thermal transitions give highly pure materials, destitute 
undesired oxide phases and organic contaminations. Because of fixed metals ratio on molecular level, final materials have specific and the same stoichiometry as starting precursor. Due to the alkoxo groups are quite easy to remove during thermal treatments, it is possible to obtain appropriate oxides in lower temperatures in contrast to conventional methods. In view of use flexibility of alkoxides, they have successfully been used in various deposition and decomposition techniques giving ultra thin layers, nanopowders and other shapes depending on potential applications.

\section{References}

1. (a) Bradley, D. C.; Mehrotra, R. C.; Rothwell, I. P. \& Singh, A. (2001). Alkoxo and Aryloxo Derivatives of Metals, Academic Press, ISBN-10: 0-12-124140-8, ISBN-13: 978-0-12124140-7, London. (b) Turova, N. Y.; Turevskaya, E. P.; Kessler, V. G. \& Yanovskaya, M. I. (2002). The Chemistry of Metal Alkoxides, Kluwer Academic Publisher, ISBN-10: 0792375211, ISBN-13: 978-0792375210, USA.

2. Veith, M. (2002). Journal of Chemical Society, Dalton Transactions, 12, 2405-2412.

3. Bradley, D. C. (1958). Nature, 182, 1211-1214.

4. (a) Szafert, S.; John, Ł.; Sobota, P. (2008). Dalton Transactions, 46, 6509-6520. (b) Starikova, Z. A.; Yanovsky, A. I.; Turevskaya, E. P. \& Turova, N. Ya. (1997). Polyhedron, 16, 967-974. (c) Goel, S. C.; Matchett, M. A.; Chiang, M. Y. \& Buhro, W. E. (1991). Journal of the American Chemical Society, 113, 1844-1845. (d) Evans, W. J.; Dominguez, R. \& Hanusa, T. P. (1986). Organometallics, 5, 1291-1296. (e) Evans, W. J.; Sollberger, M. S. \& Hanusa, T. P. (1988). Journal of the American Chemical Society, 110, 1841-1850. (f) Errington, R. J. (1998). Conference communication. (g) Hermann, W. A.; Bogdanovic, S.; Behm, J. \& Denk, M. (1992). Journal of Organometallic Chemistry, 430, C33-C38. (h) Chisholm, M. H.; Folting, K.; Hampden-Smith, M. \& Smith, C. A. (1987). Polyhedron, 6, 1747-1755. (i) Power, M. B.; Cleaver, W. M.; Apblett, A. W. A.; Barron, R. \& Ziller, J. W. (1992). Polyhedron, 11, 477-486. (j) Janas, Z.; Sobota, P.; Klimowicz, M.; Szafert, S.; Szczegot, K. \& Jerzykiewicz, L. B. (1997). Journal of Chemical Society, Dalton Transactions, 20, 3897-3902. (k) Evans, W. J.; Boyle, T. J. \& Ziller, J. W. (1993). Journal of the American Chemical Society, 115, 5084-5092. (1) Schmid, R.; Mosset, A. \& Galy, J. (1991). Acta Crystallographica, C47, 750-752. (m) Atwood, D. A.; Jegier, J. A.; Liu, S.; Rutherford, D.; Wie, P. \& Tucher, R. C. (1999). Organometallics, 18, 976-981. (n) Cotton, F. A.; Diebold, M. P. \& Roth, W. J. (1985). Inorganic Chemistry, 24, 3509-3510. (o) Chisholm, M. H.; Folting, K.; Huffman, J. C. \& Tatz, R. J. (1984). Journal of the American Chemical Society, 106, 1153-1154. (p) Goel, S. C.; Chiang, M. Y. \& Buhro, W. E. (1990). Inorganic Chemistry, 29, 4640-4646. (r) Poncelet, O.; Hubert-Pfalzgraf, L. G.; Daron, J.-C. \& Astier, R. (1989). Journal of Chemical Society, Chemical Communications, 23, 1846-1848. (s) Bradley, D. C.; Chudzynska, H.; Hursthouse, M. B.; Motevalli, M. \& Ruowen W. (1994). Polyhedron, 13, 1-6. (t) Beattie, J. K.; Hambley, T. W.; Klepetko, J. A.; Masters, A. F. \& Turner, P. (1998). Chemical Communications, 1, 45-46. (u) Evans, W. J.; Sollberger, M. S. \& Ziller, J. W. (1993). Journal of the American Chemical Society, 115, 4120-4127. (v) Mehrotra, R. C. \& Chandler, G. (1962). Journal of the Indian Chemical Society, 39, 235-240. (w) van der Boom, M. E.; Lion, S.-Y.; Ben-David, Y.; Shimon, L. J. W. \& Milstein, D. (1998). Journal of the American Chemical Society, 120, 6531-6541. 
5. Drake, S. R.; Streib, W. E.; Folting, K.; Chisholm, M. H. \& Caulton, K. G. (1992). Inorganic Chemistry, 31, 3205-3210.

6. Szilard, B. (1906). Electrochemistry, 12, 373-378.

7. Lehmkhul, H. \& Eisenbach, W. (1975). Annual Chemistry, 4, 672-691.

8. Kovsman, E. P.; Andruseva, S. I.; Solovjeva. L. I.; Fedyaev, V. I.; Adamova, M. N. \& Rogova, T. V. (1994). Journal of Sol-Gel Science and Technology, 2, 61-66.

9. Wu, Y.; Ho, Y. C.; Lin, C. C. \& Gau, H. M. (1996). Inorganic Chemistry 35, 5948-5952.

10. Mehrotra, R. C. (1981). Coordination Chemistry Reviews, 21, 113-121.

11. (a) Mehrotra, R. C. (1954). Journal of the Indian Chemical Society, 31, 904-910. (b) Mehrotra, R. C. (1953). Journal of the Indian Chemical Society, 30, 585-591. (c) Bradley, D. C.; Chakravarti, B. N.; Chatterjee, A. K.; Wardlaw, W. \& Whitley, A. (1958). Journal of Chemical Society, 99.

12. (a) Boyle, T. J.; Hernandez-Sanchez, B. A.; Baros, C. M.; Brewer, L. N. \& Rodriguez, M. A. (2007). Chemistry of Materials, 19, 2016-2026. (b) Matchett, M. A.; Chiang, M. Y. \& Buhro, W. E. (1990). Inorganic Chemistry, 29, 358-360. (c) Chisholm, M. H.; Huffman, J. C.; Kirkpatric, J.; Leonelli, J. \& Folting, K. (1981). Journal of the American Chemical Society, 103, 6093-6099.

13. (a) Neumüller, B. (2003). Chemical Society Reviews, 32, 50-55. (b) Basharat, S.; Carmalt, C. J.; Barnett, S. A.; Tocher, D. A. \& Davies, H. O. (2007). Inorganic Chemistry, 46, 94739480. (c) Basharat, S.; Betchley, W.; Carmalt, C. J.; Barnett, S.; Tocher, D. A. \& Davies, H. O. (2007). Organometallics, 26, 403-407. (d) Jerzykiewicz, L. B.; Utko, J. \& Sobota, P. (2006). Organometallics, 25, 4924-4926. (e) Sobota, P.; Utko, J.; Sztajnowska, K.; Ejfler, J. \& Jerzykiewicz, L. B. (2000). Inorganic Chemistry, 39, 235239.

14. John, Ł.; Utko, J.; Szafert, S.; Jerzykiewicz, L. B.; Kępiński, L. \& Sobota, P. (2008). Chemistry of Materials, 20, 4231-4239.

15. (a) Segal, D. (1997). Journal of Materials Chemistry, 7, 1297-1305. (b) Moulson, A. J. \& Herbert, J. M. Electroceramics: Materials, Properties and Applications, Chapman and Hall, London, 1990, p. 86.

16. Veith, M. (2002). Journal of Chemical Society, Dalton Transactions, 12, 2405-2412.

17. (a) Veith, M.; Mathur, S.; Lecerf, N.; Huch, V.; Decker, T.; Beck, H. P.; Eiser, W. \& Haberkorn, R. (2000). Journal of Sol-Gel Science and Technology, 15, 145-158. (b) Veith, M.; Mathur, S.; Huch, V. \& Decker, T. (1998). European Journal of Inorganic Chemistry, 9, 1327-1332.

18. (a) Sobota, P.; Drąg-Jarząbek, A.; John, Ł.; Utko, J.; Jerzykiewicz, L. B. \& Duczmal, M. (2009). Inorganic Chemistry, 48, 6584-6593. (b) Drąg-Jarząbek, A.; Sobota, P., submitted.

19. McElwee-White, L. (2006). Dalton Transactions, 45, 5327-5333.

20. Utko, J.; Szafert, S.; Jerzykiewicz, L. B. \& Sobota, P. (2005). Inorganic Chemistry, 44, 51945196.

21. (a) Singh, S. \& Roesky, H. W. (2007). Journal of Chemical Society, Dalton Transactions, 14, 1360-1370. (b) Sharma, M.; Singh, A. \& Mehrotra, R. C. (2002). Synthesis and Reactivity in Inorganic and Metal-Organic Chemistry, 32, 1223-1233.

22. Utko, J.; Ejfler, J.; Szafert, S.; John, Ł.; Jerzykiewicz, L. B. \& Sobota, P. (2006). Inorganic Chemistry, 45, 5302-5306. 
23. (a) Epifani, M.; Andreu, T.; Arbiol, J.; Diaz, R.; Siciliano, P. \& Morante, J. R. (2009). Chemistry of Materials, 21, 5215-5221. (b) Epifani, M.; Andreu, T.; Magana, C. R.; Arbiol, J.; Siciliano, P.; D’Arienzo, M.; Scotti, R.; Morazzoni, F. \& Morante, J. R. (2009). Chemistry of Materials, 21, 1618-1626. (c) Vioux, A. (1997). Chemistry of Materials, 9, 2292-2299. (d) Chang, S.-M.; Doong, R.-A. (2006). The Journal of Physical Chemistry B, 110, 20808-20814. (e) Tang, J.; Fabbri, J.; Robinson, R. D.; Zhu, Y.; Herman, I. P.; Steigerwald, M. L. \& Brus, L. E. (2004). Chemistry of Materials, 16, 1336-1342. (f) de A. A. Soler-Illia, G. J.; Sanchez, C.; Lebeau, B. \& Patarin, J. (2002). Chemical Reviews, 102, 4093-4138. (g) Crepaldi, E. L.; de A. A. Soler-Illia, G. J.; Grosso, D.; Cagnol, F.; Ribot, F. \& Sanchez, C. (2003). Journal of the American Chemical Society, 125, 9770-9786.

24. Hamid, M.; Tahir, A. A.; Mazhar, M.; Zeller, M. \& A. D. Hunter (2007). Inorganic Chemistry, 46, 4120-4127.

25. John, Ł. (2008). PhD Dissertation: Alkoxo metal complexes as precursors for new materials. Faculty of Chemistry, University of Wrocław, Poland.

26. John, Ł.; Krauzy-Dziedzic, K.; Drąg-Jarząbek, A. \& Sobota, P. (2010), submitted.

27. Krauzy-Dziedzic, K.; Ejfler, J.; Szafert, S. \& Sobota, P. (2008). Dalton Transactions, 19, $2620-$ 2626.

28. Sobota, P.; Przybylak, K.; Utko, J.; Jerzykiewicz, L. B.; Pombeiro, A. J. L.; Guedes da Silva, M. F. C. \& Szczegot, K. (2001). Chemistry - A European Journal, 7, 951-958.

29. Seisenbaeva, G. A.; Suslova, E. V.; Kritikos, M.; Kessler, V. G.; Rapenne, L.; Andrieux, M.; Chassagneux, F. \& Parola, S. (2004). Journal of Materials Chemistry, 14, 3150-3157.

30. Kessler, V. G.; Seisenbaeva, G. A. \& Parola, S. (2004). Journal of Sol-Gel Science and Technology, 31, 63-66.

31. Mathur, S.; Veith, M.; Ruegamer, T.; Hemmer, E. \& Shen, H. (2004). Chemistry of Materials, 16, 1304-1312.

32. Veith, M.; Mathur, S.; Lecerf, N.; Bartz, K.; Heintz, M. \& Huch, V. (2000). Chemistry of Materials, 12, 271-274. 


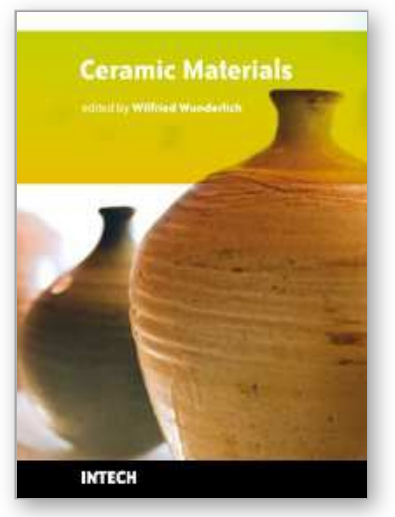

\author{
Ceramic Materials \\ Edited by Wilfried Wunderlich
}

ISBN 978-953-307-145-9

Hard cover, 228 pages

Publisher Sciyo

Published online 28, September, 2010

Published in print edition September, 2010

This is the first book of a series of forthcoming publications on this field by this publisher. The reader can enjoy both a classical printed version on demand for a small charge, as well as the online version free for download. Your citation decides about the acceptance, distribution, and impact of this piece of knowledge. Please enjoy reading and may this book help promote the progress in ceramic development for better life on earth.

\title{
How to reference
}

In order to correctly reference this scholarly work, feel free to copy and paste the following:

Lukasz John and Piotr Sobota (2010). Alkoxide Molecular Precursors for Nanomaterials: a One Step Strategy for Oxide Ceramics, Ceramic Materials, Wilfried Wunderlich (Ed.), ISBN: 978-953-307-145-9, InTech, Available from: http://www.intechopen.com/books/ceramic-materials/alkoxide-molecular-precursors-for-nanomaterials-aone-step-strategy-for-oxide-ceramics

\section{INTECH}

open science | open minds

\author{
InTech Europe \\ University Campus STeP Ri \\ Slavka Krautzeka 83/A \\ 51000 Rijeka, Croatia \\ Phone: +385 (51) 770447 \\ Fax: +385 (51) 686166 \\ www.intechopen.com
}

\author{
InTech China \\ Unit 405, Office Block, Hotel Equatorial Shanghai \\ No.65, Yan An Road (West), Shanghai, 200040, China \\ 中国上海市延安西路65号上海国际贵都大饭店办公楼 405 单元 \\ Phone: +86-21-62489820 \\ Fax: $+86-21-62489821$
}


(C) 2010 The Author(s). Licensee IntechOpen. This chapter is distributed under the terms of the Creative Commons Attribution-NonCommercialShareAlike-3.0 License, which permits use, distribution and reproduction for non-commercial purposes, provided the original is properly cited and derivative works building on this content are distributed under the same license. 